\title{
A CONSTRUÇÃO DA IMAGEM DO SUJEITO AUTISTA: UMA ANÁLISE DE DISCURSOS MIDIÁTICOS
}

\author{
Júlia Roja Tavoni, Ricardo Santhiago Corrêa, Kelly Cristina Brandão da Silva.
}

\section{Resumo}

Assumindo como ponto de partida a imagem social do sujeito autista, este estudo propõe a discussão crítica de materiais midiáticos brasileiros hegemônicos e contra hegemônicos que abordam o autismo. Determina-se como essência deste estudo a análise sobre o posicionamento de diferentes segmentos sociais perante um mesmo fenômeno e sua contribuição para a construção da imagem social sobre o indivíduo autista.

\section{Palavras-chave: Autismo, Mídia e Saúde}

\section{Introdução}

Com o aumento da visibilidade da pessoa autista na mídia, inúmeros materiais midiáticos são encontrados acerca do tema: séries de TV, documentários, novelas, blogs, grupos em redes sociais e canais do Youtube. A realidade complexa associada ao autismo, que antes era restrita ao contexto clínico, hoje é discutida abertamente com o acesso facilitado da população. Este estudo assume o desafio de compreender o modo como a dinâmica interacional das mídias hegemônicas e contrahegemônicas impacta e (re)constrói a imagem do indivíduo autista.

\section{Metodologia}

Tendo como base a análise e reflexão acerca do posicionamento de atores sociais distintos sobre o autismo, objetiva-se compreender suas respectivas contribuições à imagem da pessoa autista a partir da reflexão sobre a dinâmica interacional estabelecida entre os discursos veiculados por mídias hegemônicas e contra-hegemônicas. A coleta de dados ocorreu através de uma pesquisa netnográfica ${ }^{1}$, com a análise $e$ discussão dos materiais escolhidos na perspectiva da hermenêutica de profundidade. Realizou-se uma análise cuidadosa dos comentários online, como forma de compreender a recepção do público diante dos conteúdos veiculados.

\section{Resultados e Discussão}

A partir da análise, identificou-se que as que mídias hegemônicas e contra-hegemônicas trazem temas semelhantes à discussão, contudo assumindo diferentes perspectivas. As análises realizadas foram separadas em três eixos temáticos mais recorrentes na amostra, visando delinear algumas das forças que agem na composição da imagem do sujeito autista.

\section{A. Mito da Genialidade}

Nas mídias hegemônicas, o mito da genialidade é o ponto de partida da discussão. Nestes materiais, há a redução da condição autista a uma imagem simplificada, a qual encobre a heterogeneidade do diagnóstico. Nas mídias contra-hegemônicas, há a desconstrução dessa realidade e o destaque de relatos de familiares que reconhecem a projeção equivocada do mito da genialidade à imagem de seus filhos.

\section{B. O diagnóstico precoce e a patologização}

Nas mídias hegemônicas, destaca-se a abordagem sobre sinais clínicos isolados do autismo, os quais podem contribuir para a patologização ${ }^{2}$. O diagnóstico precoce é abordado como garantia de que o desenvolvimento do sujeito autista ocorrerá dentro das expectativas estabelecidas no desenvolvimento dito típico. Ou, ainda, destacam o diagnóstico precoce como determinante das habilidades excepcionais futuras reforçando a imagem do sujeito autista associada a elementos extraordinários como afirmação positiva da condição ${ }^{3}$. Já as mídias contrahegemônicas destacam à angústia das famílias durante o processo diagnóstico, além de comentários que retomam a popularização a respeito do mito da genialidade.

\section{Os desafios no contexto familiar}

As mídias hegemônicas retratam a dificuldade das famílias em relação à aceitação do diagnóstico e à convivência com o autismo, destacam-se as demandas da família sobre a dificuldade do sujeito autista com a afetividade e o desgaste emocional do diagnóstico. Nas mídias contra hegemônicas há a composição da imagem da pessoa autista de maneira mais dinâmica e heterogênea. Expõem-se as alterações na dinâmica familiar com o diagnóstico e o preconceito nutrido pelas imagens midiáticas construídas sobre o autismo.

\section{Conclusões}

Destaca-se neste estudo o quanto a internet e as diferentes mídias tornam-se agentes ativos na composição da imagem do sujeito autista. As mídias hegemônicas agem como porta de entrada ao tema, contribuindo para a construção de uma imagem do sujeito autista fortemente associada ao mito da genialidade, com poucas referências ao autista severo e não-verbal. Com maior destaque à heterogeneidade, as mídias contra-hegemônicas trazem relatos de núcleos familiares permeados pelo autismo, na tentativa de sensibilização do público acerca dos estereótipos construídos nas mídias hegemônicas. Reconhece-se o modo como as mídias hegemônicas e contra-hegemônicas atingem diferentes públicos, de forma interdependente, o que resulta no acesso de informações de maneira diferenciada.

\section{Agradecimentos}

Projeto financiado pelo $\mathrm{CNPq}$, com bolsa iniciação científica PIBIC.

\section{Referências Bibliográficas}

1. KOZINETS, Robert V. Netnografia: realizando pesquisa etnográfica online. Penso Editora, 2014.

2. MOYSÉS, M. A. A. A lei 13.438 é um risco à saúde das criancas. 29 de setembro de 2017. Disponível em: https://madinbrasil.org/2017/09/alei-13- 438-e-um-risco-a-saude-das-criancas/. Acesso em: 05 jun 2018

3. LACERDA, Lucelmo. Luz, Câmera, Estereótipo-Ação! A representação do autismo nas séries de TV. Revista Espaço Acadêmico, v. 17, n. 193, p. 13-22, 2017 